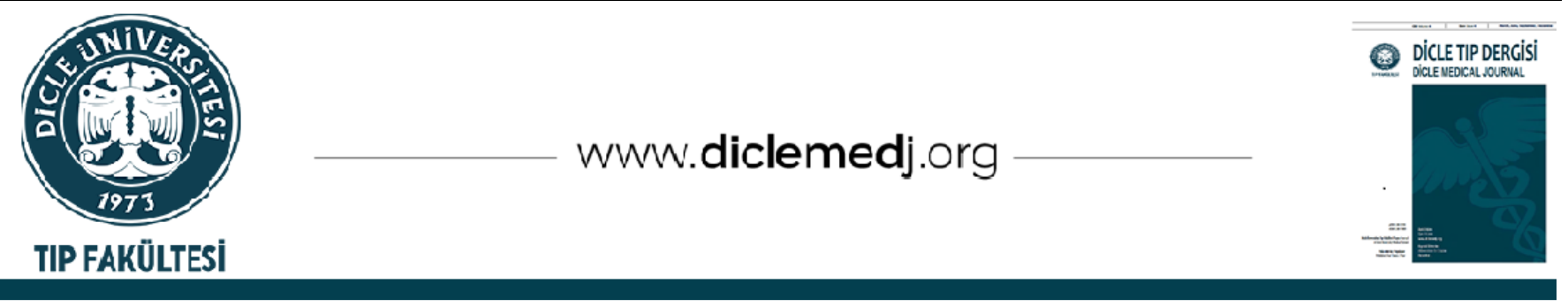

Kisa Rapor/ Brief Report

\title{
Diyarbakır Dicle Üniversitesi Hastanelerinde COVID -19 Salgınında Hastane Yönetimi
}

\author{
Mehmet Akdağ ${ }^{\text {iD }}$, Mehmet Karakoç ${ }^{\text {iD }} 4$ \\ 1 Diyarbakır Dicle Üniversitesi Hastaneleri Başhekimi, Diyarbakır, Türkiye \\ 2 Dicle Üniversitesi Rektörü, Diyarbakır, Türkiye \\ Geliş: 26.09.2021; Kabul Tarihi: 29.09.2021
}

Öz

Dicle Üniversitesi Hastanesi olarak bilimsel veriler ve sağlık bakanlığının oluşturduğu rehberler çerçevesinde planlamalar yapmış olduk. Bu çerçevede 8 ayrı başlık altında pandemi hastane yönetimini sağlamaya çalıștık. Bunlar sirasiyla;

1-Fiziksel alan planlaması

2-İnsan kaynakları yönetim

3- Lojistik destek

4-Bilimsel pandemi Kurulu

5- Laboratuarlar

6-Radyoloji

7-Ameliyethane

8-Multi kurumsal hiyerarşi

Anahtar kelimeler: COVID 19 - Hastane Yönetimi - Pandemi Hastanesi

DOI: 10.5798/dicletip.1004008

Correspondence / Yazışma Adresi: Mehmet Akdağ, Diyarbakır Dicle Üniversitesi Hastaneleri Başhekimi, Diyarbakır, Türkiye e-mail: mehmet.akdag@dicle.edu.tr 


\title{
The Hospital Management in the COVID -19 Output in Diyarbakir Dicle University Hospitals
}

\author{
Abstract \\ are respectively; \\ 1-Physical space planning \\ 2-Human resources management \\ 3- Logistic support \\ 4-Scientific Pandemic Boar \\ 5- Laboratories \\ 6-Radiolog \\ 7-Operating room \\ 8-Multi-corporate hierarchy
}

As Dicle University Hospital, it has made plans within the framework of scientific data and guidelines created by the Ministry of Health. In this context, we tried to provide pandemic hospital management under 8 different headings. These

Keyword: COVID-19 - management of Hospital - pandemic hospital.

GíRIş
Çin'in Wuhan şehrinde covid 19 salgını ile
beraber dünyaya yayılan pandemi tüm
dünyada bir çok kişinin hastalanması, yoğun
bakım da kalması ve çok sayıda da ölümlere yol
açarken covid sonrası postcovid sendromu ile
anılan bir çok organ ile ilgili kronik
komplikasyonlarla karşılaşılmış olundu.
Tabi ki bu süreçte ülkelerin sağlık sistemi ile
beraber toplumsal disiplin ve salgın yönetimi
önemlilik arzettiği gibi detayda hastane veya
salgın hastanesi yönetimi de bu anlamda hayati
önem taşımış oldu.
Biz de Dicle Üniversitesi Hastaneleri olarak
bilimsel veriler ve sağlı bakanlığının
oluşturduğu rehberler
planlamalar yapmış oldu. Bu çerçevede 8 ayrı
başlık altında pandemi hastane yönetimini
sağlamaya çalıştık.

1-Fiziksel alan planlaması

2-İnsan kaynakları yönetimi

3- Lojistik destek

4-Bilimsel pandemi Kurulu
5- Laboratuarlar

6-Radyoloji

7-Ameliyethane

7-Multi kurumsal hiyerarşi

1-Öncelikle 5 ayrı hastane binalarından biri olan kardioloji hastanemizi pandemi hastanesi olarak ilan ettik; dolayısıyla virüsten enfekte olanları ile olmayanı ve aynı zaman da başka hastalığı olup hastaneye başvuran hastaları izole etmiş olduk ve böylece fiziksel alan planlaması yapılmış oldu. Bu süreçte Kardioloji hastanemizin tek veya çift odalı olması yanında odalar içerisinde lavabo tuvaletlerinin olması bu kararda önemli etkenlerdi.

2-İnsan Kaynakları Yönetimi ise şüphesiz önemli etkendi. Bu kapsamda; doktor, hemşire, yardımcı sağlık personeli ve destek görevlileri mevcuttu.

Bu süreçte Covit ve salgın yönetimi adı altında zoom üzerinden öğretim üyelerimiz desteğinde çalıştay yapıldı ve başta araştırma görevlileri olmak üzere hemşire ve diğer yardımcı sağlık personellerine salgından korunma ve tedavi yönünde yaklaşım eğitimi verilmiş oldu. Çünkü 
bir taraftan bilimsel rehberler çerçevesinde hasta tedavisi planlanırken bir taraftan personelin kendisini de koruyor olabilir olması iş sağlığı ve güvenliği açısından önemli kurallardı. Ayrıca hastane ve iş sağlı̆̆ı güvenliği departmanı tarafından tesbit edilen öneriler de dikkate alınarak hazırlıklar planlandı. $\mathrm{Bu}$ planlamalarda gerek insan kaynakları ve gerekse tedavide kullanılan ve yüksek riskli donanımlı cihaz yönetimi önemlilik arzediyordu. Burada hastane bünyesinde özellikle yoğun bakım uzmanı olan öğretim üyeleri ve bu konuda eğitim sertifikası olan hemşirelerin önemliliği tartışılmaz bir insan kaynaklarımız idi. Dolayısıyla Dicle Üniversitesi Hastanesi olarak bu sürece çok hazırlıksız yakalanmadığımızı ifade edebiliriz. Ayrıca pandemide çalışan personelin bu zorlu ve riskli ortamda çalışma motivasyonu ve verimliliğini artırma adına performans katsayıları olumlu şekilde etkileyecek performans komisyon kararı ile ek ödemeleri artırlarak bu süreçte döner sermayeden ek bütçe harcanmış olduğunu hatırlatmak isteriz.

Ayrıca ilgili hastaların psikolojik durumları dikkate alınarak izolasyon sürecinde psikiyatri ve psikolog konsültasyonu ile takip ve tedavi,

İmmobilizasyon ve izolasyon sürecinden dolayı kas-iskelet sistem desteği ve rehabilitasyonu için fizik tedavi ve fizyoterapistler ile destek,

Hastalık süreci döneminde gerek hastalığın etkisi nedeni ile oluşan iştahsızlı (koku ve tad bozukluğu vb) ve gerekse entübe hastaların parenteral beslenmesi dikkate alınarak diyetisyen ve yoğun bakım uzman önerileri ile sağlıklı ve destekleyici beslenme planlanması yapılmış oldu. Yine beslenme ile ilişkili olarak pandemi kurallarına göre kişiye has kapaklı yemek tabldot ve içecek hizmeti verildi.

Ayrıca pandemi olmayan ana bina ve diğer hastanelerimizde gerek ziyeretçi kısıtlaması ve HES uygulamaları ile olabildiğince planlı bir koordinasyon sağlanmaya çalışıldı.
3-Lojistik destekte de aynen insan kaynakları kadar önemli olup birbirleri ile ilintili önemli parametrelerdendir. Çünkü bu süreçte dezenfektanlar, eldiven, maske, koruyucu gözlük ve formalar, mekanik ventilatörler, hight flow cihazlar, oksijen sensörleri, ve bir çok farklı solunum aparatları ile beraber hastaneler bünyesindeki oksijen tankları ile beraber yedek oksijen tüpleri önemli idi. Hastane fiziksel yapısı içerisindeki su, elektrik ve sair teknik altyapınızın da bu süreçte yeterli kapasitede olmasının yanında yedek alt yapı süreçlerinin hazır vaziyette olması gerekiyor ki acil durumda zaman kaybetmeden hızlıca devreye giriyor olması gerekir. Hatta bu süreçte ilgili teknik detayları bilen ve zamanında müdahele yapan teknik elemanlarının olması gerektiğini unutmamak gerekir.

4- Bilimsel pandemi kurulu bütün bu pandemi sürecinde gerek koruyucu tedbirleri alma hususunda gerek personel planlaması konusunda ve gerekse mevcut hastanemizdeki haftalık değerlendirmeler yapılarak alınan veriler çerçevesinde karar alma sürecinde kendi alanlarında gerek uzman öğretim üyelerinden oluşan ve gerekse bu kararların uygulayıcılarından oluşan komisyon oluşturmamız kuşkusuz önemli idi. Tabi ki tüm bu süreçte yasal mevzuat ve bilimsel kurallar çerçevesinde karar alma konusunda hastane yönetim sürecimizde pandemi ile ilgili önemli kararlar alınmasında önemli katkılar sağlamıștır. $\mathrm{Bu}$ komisyonda; Enfeksiyon hastalıkları, Anestezi ve Yoğun bakım, Halk sağlı̆̆ı, Göğüs ve Aile hekimliği uzmanlığında bulunan öğretim üyeleri ile beraber başhekim ve yardımcıları, başhemşirelik ve hastane müdüründen oluşuyordu. İlgili komisyon kurul öncesi sahada belirlenen problem veya güncellenen yeni kararları tartışılarak sürece göre yeni karar alma veya değerlendirme konusunda her hafta toplanıyordu. 
5-Mikrobiyoloji ve Biyokimya laboratuarları gerek PCR testleri ve gerekse d-Dimer ve diğer biyokimyasal ve mikrobiyolojik parametreler çalışılarak gerek ilk tanı aşaması ve gerekse hastalığın ilerleme veya nekahet dönemine geçişini takip edilmesi sağlanmış oluyordu.

6-Radyoloji; gerek tanı ve gerekse tedaviyi takip açısından önemli idi. Çünkü PCR negatif hastası olup solunum problemi yaşayan hastalarda erken akciğer tutulumu ve tutulumun karakteristik özellikleri dikkate alınarak şüpheli covid açısından takipli hastalar şüpheli covid hasta kliniğine yatırılarak takip edildi. Tomografik çekimler ana binadan ayrı onkoloji binasında yoğunluklu olarak covid hastalarına çekim planlanmış oldu. Yine bu süreçte tam donanımlı ve koruyucu ekipman ve personel desteği olan ambulanslar ile hasta trafiği planlanmış olundu. Tabiki raporlandırma sürecinde; sürekli aynı ve Torax Radyolojisinde spesifikleșmiş öğretim üyemiz desteği ile sağlanmış olundu.

7-İl valiliği, Sağlık müdürlüğü ve bağlı olduğu ile kurumlar ile gerek il bazında ve gerekse ilçe ve il dışından gelen hastalar 112 aracılığı ile multidisipliner ve multihiyerarşi içerisinde hasta sağlığı ve ileri düzey tedavi ve yatak durumu dikkate alınarak pandemi hastanesi koordinatörleri aracılığıyla senkronize çalışılmış olundu.

8-PCR testi pozitif olan veya yatıorken herhangi bir girişim veya cerrahi gerektiren hastalar için pandemi hastanesinin ameliyethanesinde ek anestezi ekibi ve enstrüman desteği ile hizmet verildi.

Yukarıda da özetle belirtildiği gibi Diyarbakır Dicle Üniversitesi hastaneleri ekibi olarak bu tedbir ve uygulamalar ile;
1-Pandemi hastanesinde yatan hastaların tanı ve tedavisini başarıyla yürütmüștür ve halen yürütmektedir.

2-PCR testi ile gerek pandemi ve gerekse zaman zaman sağlık müdürlü ve diğer kurumlara hizmet vermiştir.

3- Ayrıca başhekimlik olarak bir çok açıdan başarıll, iyi bir iletişim, koordinasyon ve bilimsel destekten dolayı Sağlık Müdürlüğünden teşekkür belgesini hak kazanmıștır.

Özetle ve son söz olarak pandemi sürecinde sağlık bakanlığı ve Dünya Tıbbi bilimsel literatürler algoritmaları çerçevesinde pandemi kurul kararlarımız ile ergonomik, senkronize çalışarak hastalarımızın tanı ve tedavisinde görev alıp büyük sorumluluk üstlenen tüm Dicle Üniversitesi Hastanesi üyesi çalışma arkadaşlarımıza ve ülkemizdeki tüm sağlık çalışanlarına göstermiş oldukları destek, fedekarlık ve özverileri için canı gönülden teşekkür ederiz. Yine bu süreçte gece gündüz demeden sürekli desteğini esirgemeyen Dicle Üniversitesi Rektörümüze tüm akademik ve diğer personelimiz adına sonsuz teșekkürlerimi sunarım. Ayrıca öğretim üyeleri ve araştırma görevlileri planlamasında Tıp fakültesi dekanlığına, il valilik ve sağlık müdürülügümüze ayrıca teșekkürlerimi ifade etmek isteriz. Ayrıca bu süreçte pandemi tanı ve tedavisinde çalışıyorken hayatını kaybeden öğretim üyesi, araştırma görevlisi, hemșire, yardımcı sağlık personelleri başta olmak üzere ülkemizde ve tüm dünyada hayatını kaybeden insanlara Yüce Allahtan rahmet dilerim. Dünyamızın ve tabi ki ülkemizin pandemisiz sağlıkl, huzurlu ve mutlu günler geçirmesi umut ve dileğimizle. 